\title{
INDICATION OF OIL PALM (Elaeis guineensis Jacq.) RESISTANCE TO Curvularia LEAF SPOT DISEASE BY PR-PROTEINS PRODUCING ABILITY
}

\author{
JITTRA KITTIMORAKUL*; THEERA EKSOMTRAMAGE*; ANURAG SUNPAPAO** and \\ THANUNCHANOK CHAIRIN**
}

\begin{abstract}
Curvularia leaf spot disease of oil palm seedlings caused by Curvularia oryzae is an important disease and widespread in South-east Asia. In this study, the resistance of oil palm C. oryzae was indicated after treatment with $10^{6}$ spores $\mathrm{ml}^{-1}$ of $\mathrm{C}$. oryzae NK1. The PR-proteins (chitinase and $\beta$-1,3-glucanase) were detected within $24 \mathrm{hr}$. From the inoculated oil palm seedlings, lines 129 and 187 were indicated as susceptible and resistant lines, respectively based on activities of the pathogenesis-related (PR)-proteins. The chitinase and $\beta$-1,3-glucanase activities of line 187 were $14.03 \pm 0.87$ and $13.51 \pm 1.04 \mathrm{U} \mathrm{ml}^{-1}$, while the respective activities of line 129 were much lower at $3.76 \pm 0.41$ and $4.31 \pm 0.83 \mathrm{U} \mathrm{ml}^{-1}$ and not significantly different from control plant. The sodium dodecyl sulphate polyacrylamide gel electrophoresis (SDS-PAGE) analysis showed accumulation of 22, 25 and $33 \mathrm{kDa}$ in inoculated line 187, whereas protein bands of line 129 were not visible. The disease symptoms in the susceptible line appeared approximately on $10 \%$ of the leaf area after $72 \mathrm{hr}$ of fungal inoculation while no leaf spot symptoms were visible in the resistant line. Thus, the resistance of oil palm against Curvularia leaf spot disease was successfully indicated based on PR-protein producing ability, prior to testing with inoculation.
\end{abstract}

Keywords: PR-protein, chitinase, $\beta-1,3$-glucanase, resistance, indication.

Date received: 22 February 2019; Sent for revision: 4 April 2019; Accepted: 11 October 2019; Available online: 30 June 2020.

\section{INTRODUCTION}

Oil palm (Elaeis guineensis Jacq.) is a monoecious and cross-pollinated plant. Tenera hybrid variety is the result of hybridising dura and pisifera and has a high commercial value (Verheye, 2010). Indonesia, Malaysia and Thailand are the most important producers of palm oil for international

\footnotetext{
Department of Plant Science,

Faculty of Natural Resources,

Prince of Songkla University,

Hat Yai, Songkhla 90110,Thailand.

** Department of Pest Management,

Faculty of Natural Resources,

Prince of Songkla University,

Hat Yai, Songkhla 90110, Thailand.

E-mail: thanunchanok.c@psu.ac.th
}

trade supplying food industry, cosmetics and renewable energy. However, the main factors that should be considered for supporting oil palm production include plantation area, diseases, agronomic methods, environment and highperformance variety. Recently, Curvularia leaf spot disease caused by Curvularia oryzae is an important disease in seedlings of tenera hybrid variety of oil palm, in the nurseries in southern Thailand (Sunpapao et al., 2014). This disease usually infects 2-3 months old oil palm seedlings and decreases both quality and quantity of the seedlings (Kittimorakul et al., 2013). Chemical, biological and mechanical controls are applied to the leaf spot disease in the nurseries, but the pathogen usually attacks every year in the beginning of the rainy season. 
Higher plants possess a broad range of mechanisms to protect themselves against various threats and stresses, especially against attacks by pathogens including fungi, bacteria and viruses (Agrios, 1997). These stresses induce reactions such as producing phenolic compounds, phytoalexins and pathogenesis-related (PR) proteins that subsequently prevent invasion by various pathogens (Bowles, 1990). Among the PR-proteins, chitinase and $\beta$-1,3-glucanase are two important hydrolytic enzymes that are produced in many plant species after infection by various pathogens (Ebrahim et al., 2011). The chitinases and glucanases are thought to limit fungal growth as chitin and glucans are widely distributed in the cell walls of fungal pathogens. This anti-fungal function has been demonstrated in vitro against several fungal pathogens not only on plant leaf diseases but also on root diseases such as black spot disease caused by Alternaria brassicicola in rocket salad (Gupta et al., 2013), leaf blight pathogen (A. palandui) in onion (Karthikeyan et al., 2005), late blight disease caused by Phytophthora infestans in tomato (Anfoka and Buchenauer, 1997), necrogenic fungus (Colletotrichumlagenarium) of cucumber leaves (Ji and Kie, 1996) and root rot disease of cocoyam caused by Pythium myriotylum (Nyochembeng and Beyl, 2015). Thus, these enzymes are important determinants of the resistance of plants to fungal diseases (Funnell et al., 2004). Chitinase and $\beta-1,3-$ glucanase have synergistically stronger anti-fungal activity against a wider range of fungi when used in combination than when acting singly (Mauch et al., 1988).

In oil palm breeding programme, aside from palm oil yield, disease resistance is also an important characteristic required of a high performance variety. Oil palm basal stem rot caused by Ganoderma sp. has been widely reported in oil palm plantations and included in oil palm breeding programmes (Idris et al., 2004; Durand-Gasselin et al., 2005). However, there are only a few studies on Curvularia leaf spot disease, and most have focused on chemical and biological control. Therefore, the purpose of this current study was to indicate, based on PR-protein producing ability, oil palm lines resistant to leaf spot disease (C. oryzae).

\section{MATERIALS AND METHODS}

\section{Plant Materials}

Ten different genotypes of oil palm tenera hybrid (Dura $\times$ Pisifera), lines 117, 129, 138, 155, 177, 187, 188, 202/6, 203 and 207, were initially selected from 124 lines by detached leaf method. Then, seedlings of these 10 genotypes were subjected to pathogenicity test to study their resistance against $C$. oryzae at the Oil Palm Agronomical Research Centre: Phase
2, Department of Plant Science, Faculty of Natural Resources, Prince of Songkla University, Thailand (Kittimorakul et al., 2019) to separate resistance and susceptible lines before further testing for enzyme activities. The seedlings chosen for this study were 3-4 months old, raised in the greenhouse conditions with temperature varying between of $25^{\circ} \mathrm{C}-30^{\circ} \mathrm{C}, 60 \%$ $\pm 5 \%$ relative humidity $(\mathrm{RH})$, and $12 \mathrm{hr}$ photoperiod. The experiments followed a completely randomised design (CRD) with four replicates per line (one seedling per one replicate).

\section{Fungal Culture and Inoculation}

The virulent strain C. oryzae NK1 (Kittimorakul et al., 2014) was used to inoculate oil palm seedlings. The fungus was transferred from potato dextrose agar slants to corn meal agar, and incubated at room temperature $\left(25^{\circ} \mathrm{C}-28^{\circ} \mathrm{C}\right)$ for 20 days. Spore suspensions were prepared with sterilised distilled water and adjusted to $1 \times 10^{6}$ conidia $\mathrm{ml}^{-1}$ under aseptic conditions. To inoculate, the oil palm seedlings were each sprayed with 20 $\mathrm{ml}$ spore suspension, while plants sprayed with sterile distilled water served as uninoculated controls. Seedlings were covered with plastic bags and incubated for $48 \mathrm{hr}$ to stimulate the pathogen infection.

\section{Crude Enzyme Extraction}

Forty-eight hours after inoculation, $1 \mathrm{~g}$ of oil palm leaf from each plant was sampled for crude enzyme extraction. The tissue was crushed in a cooled mortar with pestle, in $5 \mathrm{ml}$ of $50 \mathrm{mM}$ potassium phosphate buffer ( $\mathrm{pH}$ 7.0) for chitinase and with $50 \mathrm{mM}$ acetate buffer ( $\mathrm{pH}$ 5.0) for $\beta-1,3-$ glucanase. Then, the leaf extracts were transferred to microcentrifuge tubes $(1.5 \mathrm{ml})$ and centrifuged at $10000 \mathrm{rpm}$ for $5 \mathrm{~min}$. The supernatant (crude enzyme) was transferred to a new microcentrifuge tube and stored at $2^{\circ} \mathrm{C}-4^{\circ} \mathrm{C}$ until use in enzyme activity determination.

\section{Chitinase Assay}

The reaction mixture consisted of $250 \mu \mathrm{l}$ sample and $250 \mu \mathrm{l}$ of $1 \%$ colloidal chitin as a substrate in $50 \mathrm{mM}$ potassium phosphate buffer at $\mathrm{pH}$ 7.0. The mixture was incubated at $37^{\circ} \mathrm{C}$ for $30 \mathrm{~min}$. After incubation, $500 \mu \mathrm{l}$ of dinitrosalicylic acid solution (DNS) was added. The enzyme activity was stopped by heating the mixture to $100^{\circ} \mathrm{C}$ for $15 \mathrm{~min}$, and then cooled at room temperature. Then, $4 \mathrm{ml}$ of distilled water was added and the enzyme activity was determined by measuring the absorbance at 575 $\mathrm{nm}$. One unit (U) of chitinase activity was defined as releasing $1 \mu \mathrm{mol}$ of $\mathrm{N}$-acetyl-D-glucosamine from the substrate per min. 


\section{$\beta-1,3-$ glucanase Assay}

The $\beta$-1,3-glucanase activity was measured using laminarin as a substrate. The reaction mixture $(250 \mu \mathrm{l})$ consisted of $125 \mu \mathrm{l}$ sample and 125 $\mu \mathrm{l}$ of $1 \%$ laminarin in $50 \mathrm{mM}$ acetic acid buffer at $\mathrm{pH}$ 5.0. The mixture was incubated at $37^{\circ} \mathrm{C}$ for 30 min. After incubation, $250 \mu$ of DNS was added. The enzyme activity was stopped by heating the mixture to $100^{\circ} \mathrm{C}$ for $15 \mathrm{~min}$ and then cooled at room temperature. Then, $2 \mathrm{ml}$ of distilled water was added. Enzyme activity was determined by measuring the absorbance at $550 \mathrm{~nm}$. One unit (U) of $\beta$-1,3-glucanase activity was defined as releasing $1 \mu \mathrm{mol}$ of glucose from the laminarin per min.

\section{Chitinase and $\beta-1,3$-glucanase Activities from the Selected Oil Palm Seedlings}

The oil palm seedling lines were selected based on the previous experiment (one line from the highest activities and one line from the lowest activities) and evaluated for activity time-profiles of two PR-proteins, chitinase and $\beta-1,3$-glucanase. One gram fresh weight leaf samples were collected from the selected lines at $0,24,48,72,96,120,144$ and $168 \mathrm{hr}$ after inoculation with the fungal pathogen. The samples were extracted and centrifuged. Crude extracts were measured for the enzyme activities.

\section{Protein Assay}

The total protein in oil palm leaf extracts was determined by the method of Bradford (1976) using bovine serum albumin (BSA) as a standard. The reaction mixture containing $0.1 \mathrm{ml}$ of sample and $5 \mathrm{ml}$ of protein reagent [Coomassie Brilliant Blue G-250 dissolved in 95\% ethanol and 85\% (w/v) phosphoric acid] was incubated for $5 \mathrm{~min}$ and the developed colour was determined at $595 \mathrm{~nm}$.

\section{Sodium Dodecyl Sulphate Polyacrylamide Gel Electrophoresis (SDS-PAGE)}

Crude extracts from oil palm leaves were applied to mini-gels $(12 \%$ separating gel and $4 \%$ stacking gel) to determine proteins by molecular mass in the crude extracts, according to the procedure of Laemmli (1970). Samples of approximately $20 \mu \mathrm{l}$ were loaded in each well and electrophoresis was performed at $100 \mathrm{~V}$ constant voltages for the stacking gel (15 $\mathrm{min})$ and at $120 \mathrm{~V}$ for the separating gel $(45 \mathrm{~min})$. The proteins were fixed and stained for $15 \mathrm{~min}$ in Coomassie blue (R-250) staining solution. After staining, the gels were washed with a destaining solution and slowly shaken on a horizontal rotator for about $10 \mathrm{~min}$. The destaining solution was refreshed twice. Then, the samples were incubated overnight in distilled water. The molecular masses of resolved proteins were estimated by electrophoresis of the marker proteins (BioLabs Inc.) with molecular masses ranging within 11-245 $\mathrm{kDa}$.

\section{Statistical Analysis}

The enzyme activities (mean values) were subjected to analysis of variance (ANOVA) using the generalised linear model (GLM) procedure and Tukey's HSD test $(P \leq 0.05)$ in SPSS software (Version 16.0).

\section{RESULTS AND DISCUSSION}

Chitinase and glucanase are produced in many higher plant species after induction by fungal inducers. These enzymes can inhibit fungal growth and play a role in self-defense (Ham et al.,1991) because the major components of fungal cell walls are the polysaccharides, chitin and glucan, which are the substrates for chitinase and glucanase (SelaBuurlage et al., 1993). Prior studies have reported that when coconut (Cocos nucifera L.) root was treated with Pseudomonas fluorescens, Trichoderma viride and T. harzianum in combination with chitin, it produced chitinase and $\beta-1,3$-glucanase against Ganoderma lucidum (Karthikeyan et al., 2006). Chairin and Petcharat (2017) reported that in longkong fruit (Aglaia dookkoo Griff.) chitinase and $\beta$-1,3-glucanase were detected in peel extracts after exposure to the fungus Metarhizium guizhouense, and these inhibited the mycelial growth of fruit rot fungi, Fusarium sp. and Botrytis sp. In this current study, oil palm plants were treated with $C$. oryzae and this activated PRproteins, chitinase and $\beta-1,3$-glucanase. Forty-eight hours after the fungal inoculation, the oil palm lines 138 and 187 showed high chitinase activities at $14.88 \pm 1.31$ and $17.84 \pm 1.46 \mathrm{U} \mathrm{ml}^{-1}$, respectively, and $\beta$-1,3-glucanase activities at $12.02 \pm 1.03$ and $14.23 \pm$ $1.31 \mathrm{U} \mathrm{ml}^{-1}$, in the same order. lines 138 and 187 were not significantly different at $P \leq 0.05$. In contrast, lines 117, 129 and 155 presented low activities of both enzymes and were not significantly different $(P \leq 0.05)$ from the uninoculated controls in $\beta-1,3-$ glucanase activity (Table 1). Not only for enzyme activities results, but Kittimorakul et al. (2019) also reported that lines 117, 129 and 155 were susceptible lines because of rapid manifestation of disease symptom (three days after inoculation), high disease score $(3.10,4.55$ and 3.70) and high percentage of disease incidence $(62 \%, 91 \%$ and $74 \%)$. Based on the enzyme activity results, two candidate lines were selected from the 10 lines tested. Oil palm line 187 was selected for its high enzyme activities, while line 129 was selected for its comparatively low activities. These selected oil palm lines were then assessed for the time profiles of enzyme activity, for 
proteins with SDS-PAGE, and for disease symptom occurrence.

The chitinase and $\beta-1,3$-glucanase activities of the selected oil palm lines were determined every $24 \mathrm{hr}$ over seven days after inoculation with the fungus. It was found that the chitinase activity of line 187 was $14.03 \pm 0.87 \mathrm{U} \mathrm{ml}^{-1}$ at $24 \mathrm{hr}$, peaked to 16.84 $\mathrm{U} \mathrm{ml}^{-1}$ at $48 \mathrm{hr}$ and then decreased continuously to $5.77 \mathrm{U} \mathrm{ml}^{-1}$ at $168 \mathrm{hr}$. For line 129, chitinase activity at $3.76 \pm 0.41 \mathrm{U} \mathrm{ml}^{-1}$ was observed at $24 \mathrm{hr}$ and it decreased slightly to $1.25 \mathrm{U} \mathrm{ml}^{-1}$ at $168 \mathrm{hr}$ after inoculation (Figure 1a). Regarding $\beta$-1,3-glucanase, the enzyme activity in oil palm line $187 \mathrm{at} 24 \mathrm{hr}$ after inoculation was $13.51 \pm 1.04 \mathrm{U} \mathrm{ml}^{-1}$, the highest at
$15.02 \mathrm{U} \mathrm{ml}^{-1}$ activity was at $48 \mathrm{hr}$, and the activity then decreased continuously to $4.50 \mathrm{U} \mathrm{ml}^{-1}$ at 168 $\mathrm{hr}$. In contrast, the $\beta$-1,3-glucanase activity of line $129\left(4.31 \pm 0.83 \mathrm{U} \mathrm{ml}^{-1}\right.$ at $\left.24 \mathrm{hr}\right)$ was not significantly different from its uninoculated control (Figure 1b). The proteins in oil palm leaves were separated by SDS-PAGE and stained with Coomassie blue R-250 to observe the protein bands. The SDS-PAGE analysis showed differences in the expression of major proteins in the selected oil palm lines 129 and 187 from their uninoculated controls. Oil palm line 129, which produced low activities of chitinase and $\beta$-1,3-glucanase, did not have visible protein bands. However, line 187 had protein bands for 22,

TABLE 1. ENZYME ACTIVITIES (mean \pm standard deviation) OF OIL PALM LEAF EXTRACTS 48 hr AFTER INOCULATION

\begin{tabular}{|c|c|c|c|c|}
\hline \multirow{2}{*}{ Line number } & \multicolumn{2}{|c|}{ Chitinase $\left(\mathrm{U} \mathrm{ml}^{-1}\right)^{*}$} & \multicolumn{2}{|c|}{$\beta$-1,3-glucanase $\left(\mathrm{U} \mathrm{ml}^{-1}\right)^{*}$} \\
\hline & Control plants & Fungal treated plants** & Control plants & Fungal treated plants ${ }^{* *}$ \\
\hline 117 & $2.26 \pm 0.19^{\mathrm{B}}$ & $6.85 \pm 1.40^{\text {Adef }}$ & $2.04 \pm 0.18^{\mathrm{A}}$ & $3.50 \pm 1.07^{\mathrm{Afg}}$ \\
\hline 129 & $0.41 \pm 0.16^{\mathrm{B}}$ & $3.27 \pm 0.27^{\mathrm{Af}}$ & $0.90 \pm 0.19^{\mathrm{A}}$ & $2.05 \pm 0.70^{\mathrm{Ag}}$ \\
\hline 138 & $3.11 \pm 0.74^{\mathrm{B}}$ & $14.88 \pm 3.62^{\mathrm{Aab}}$ & $2.98 \pm 0.09^{\mathrm{B}}$ & $12.02 \pm 1.03^{\mathrm{Aab}}$ \\
\hline 155 & $1.48 \pm 0.36^{\mathrm{B}}$ & $4.61 \pm 0.60^{\text {Aef }}$ & $1.97 \pm 0.21^{\mathrm{B}}$ & $4.91 \pm 0.16^{\text {Aef }}$ \\
\hline 177 & $2.89 \pm 0.79^{\mathrm{B}}$ & $7.16 \pm 1.15^{\text {Ade }}$ & $1.79 \pm 0.33^{\mathrm{B}}$ & $7.04 \pm 1.00^{\text {Ade }}$ \\
\hline 187 & $3.36 \pm 0.95^{\mathrm{B}}$ & $17.84 \pm 1.46^{\mathrm{Aa}}$ & $4.00 \pm 0.09^{\mathrm{B}}$ & $14.23 \pm 1.31^{\mathrm{Aa}}$ \\
\hline 188 & $3.34 \pm 0.80^{\mathrm{B}}$ & $12.56 \pm 1.30^{\mathrm{Abc}}$ & $3.17 \pm 0.61^{\mathrm{B}}$ & $10.09 \pm 1.47^{\mathrm{Abc}}$ \\
\hline 202.6 & $2.25 \pm 0.50^{\mathrm{B}}$ & $9.76 \pm 0.78^{\mathrm{Acd}}$ & $1.89 \pm 0.11^{\mathrm{B}}$ & $8.18 \pm 0.79^{\text {Acd }}$ \\
\hline 203 & $3.05 \pm 0.67^{\mathrm{B}}$ & $13.57 \pm 1.07^{\mathrm{Ab}}$ & $2.36 \pm 0.39^{\mathrm{B}}$ & $11.70 \pm 1.36^{\mathrm{Ab}}$ \\
\hline 207 & $3.17 \pm 0.15^{\mathrm{B}}$ & $12.51 \pm 1.03^{\mathrm{Abc}}$ & $2.88 \pm 0.97^{\mathrm{B}}$ & $11.17 \pm 0.83^{\mathrm{Ab}}$ \\
\hline
\end{tabular}

Note: * Same capital superscript in a row indicates no significant difference by Least Significant Difference test $(P \leq 0.05)$.

** Same lower case superscript in a column indicates no significant difference by Least Significant Difference test $(P \leq 0.05)$.

(a)

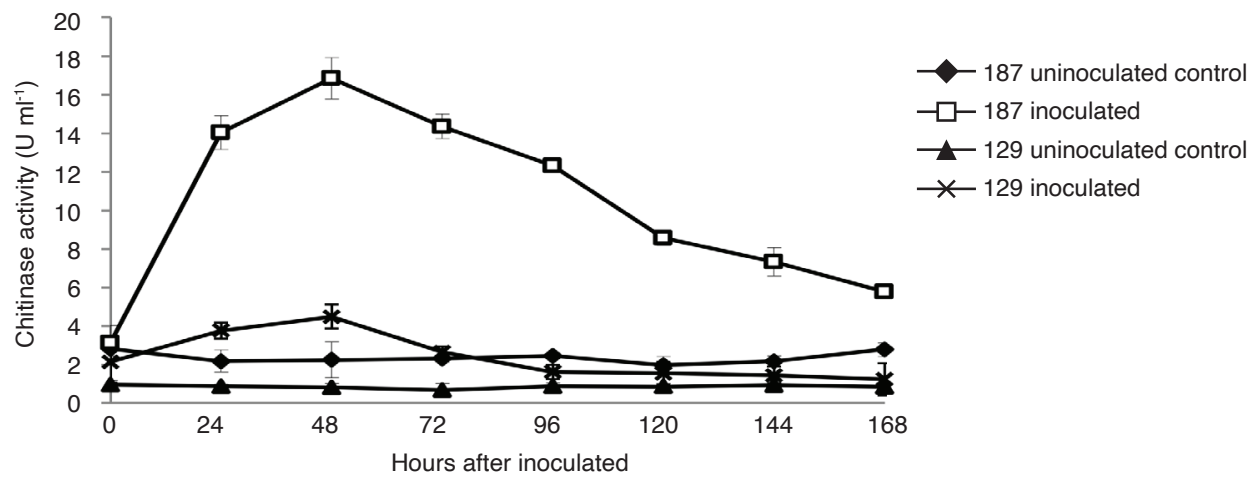

(b)

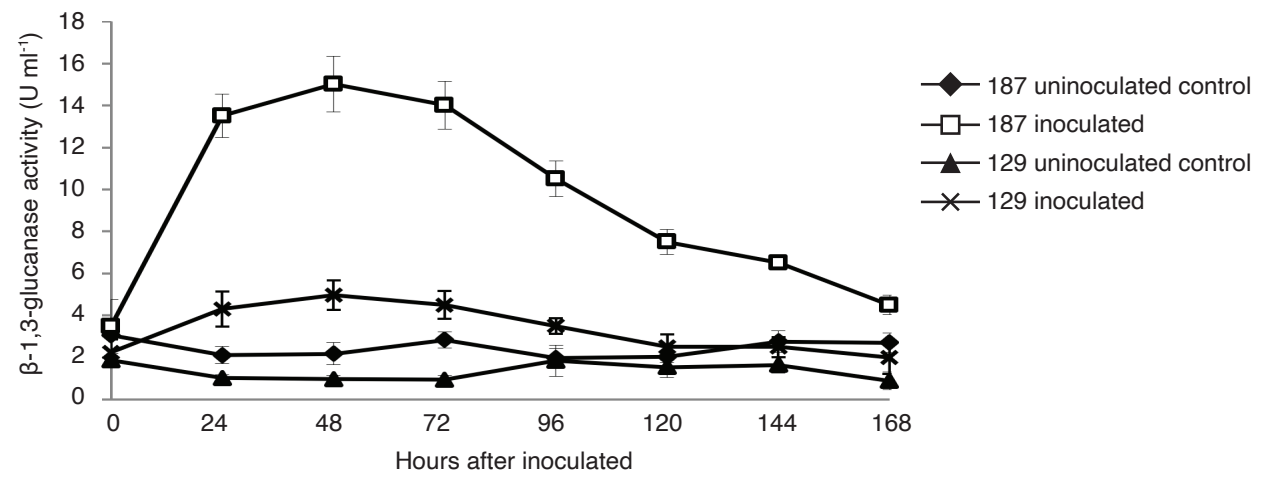

Figure 1. Enzyme activities of oil palm leaf extracts in control and Curvularia inoculated cases: (a) chitinase activity, and (b) $\beta$-1,3-glucanase activity. 
25 and $33 \mathrm{kDa}$ at $24 \mathrm{hr}$, and the bands were darker at $48 \mathrm{hr}$ after fungal inoculation (Figure 2). Hegde and Keshgond (2013) reported that most plant chitinases have molecular mass in the range from 15 to $43 \mathrm{kDa}$, and plant glucanases have molecular mass from 33 to $44 \mathrm{kDa}$. In addition, Syahanim et al. (2013) reported that several proteins with molecular weights of less than $50 \mathrm{kDa}$ were expressed in oil palm root on Days 3 and 7 after Ganoderma boninense infection, and one of these was glucanase.

The observations of PR-proteins, chitinase and $\beta$-1,3-glucanase in this study were related to disease symptom occurrence that also differed between oil palm lines 129 and 187 after Curvularia inoculation. In the high enzyme activity line 187, no disease symptoms were visible at $72 \mathrm{hr}$ after fungal inoculation. In contrast, line 129 with low activities of PR-proteins had small light brown lesions, 1-2 $\mathrm{mm}$ in size, covering approximately $10 \%$ of leaf area (Figure 3). In the disease symptom index of Kittimorakul et al. (2014), the rapid appearance of small lesions over approximately $1 \%-10 \%$ of leaf area distinguishes the susceptible lines, while the genotypes that have no or delayed lesions on leaves are considered resistant. Based on our observations on PR-proteins and disease symptoms, oil palm line 129 was susceptible while line 187 was resistant in that indexing system.

Analogous observations by Pareek et al. (2013) show higher chitinase and $\beta$-1,3-glucanase activities response to the fungal pathogen Macrophomina phaseolina in the resistant moth bean cultivar (FMM-96) over the susceptible cultivar (RM0-40 and CZM-3). Anguelova-Merhar et al. (2001) found that the wheat plant resistant line (Kareee/Lr35)

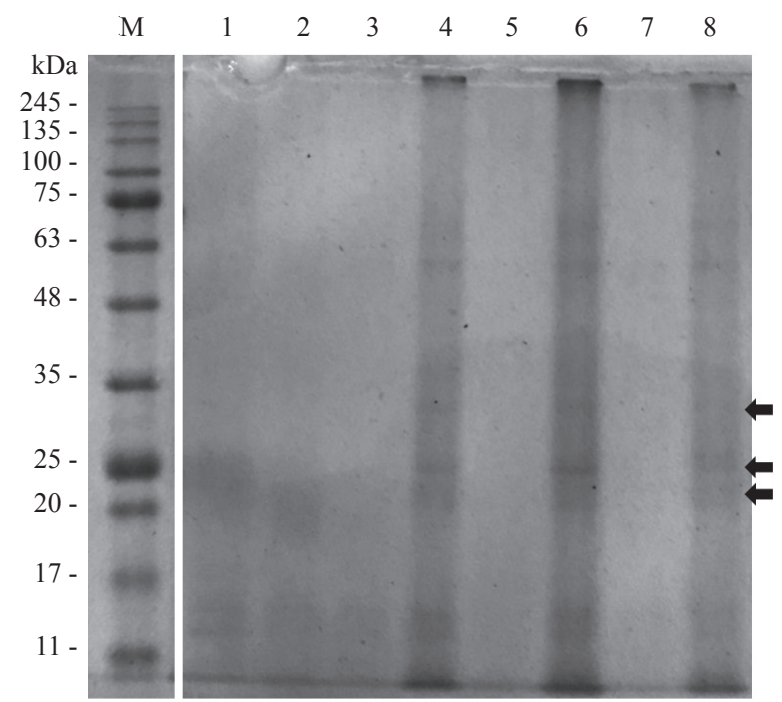

Figure 2. Sodium dodecyl sulphate polyacrylamide gel electrophoresis (SDS-PAGE) protein bands for oil palm leaf extracts after Curvularia leaf spot inoculation. Lane M: protein marker, lane 1: uninoculated control of line 129, lane 2: uninoculated control of line 187, lanes 3, 5 and 7: line 129 at 24, 48 and $72 \mathrm{hr}$, respectively, and lanes 4, 6 and 8: line 187 at 24, 48 and $72 \mathrm{hr}$, respectively. had higher chitinase and $\beta$-1,3-glucanase activities after inoculation with leaf rust pathogen (Puccinia recondite f. sp. tritici) than the susceptible line (Karee). In this current study, PR-protein activation could be detected within $24 \mathrm{hr}$ after Curvularia inoculation, before the disease symptoms that appeared at $72 \mathrm{hr}$ for the susceptible line, and not before $168 \mathrm{hr}$ for resistant line. The early enzyme activities significantly differed between the resistant and susceptible lines. Thus, PR-protein producing ability could be used to indicate oil palm lines resistant to Curvularia leaf spot disease, independently of disease symptom occurrence.

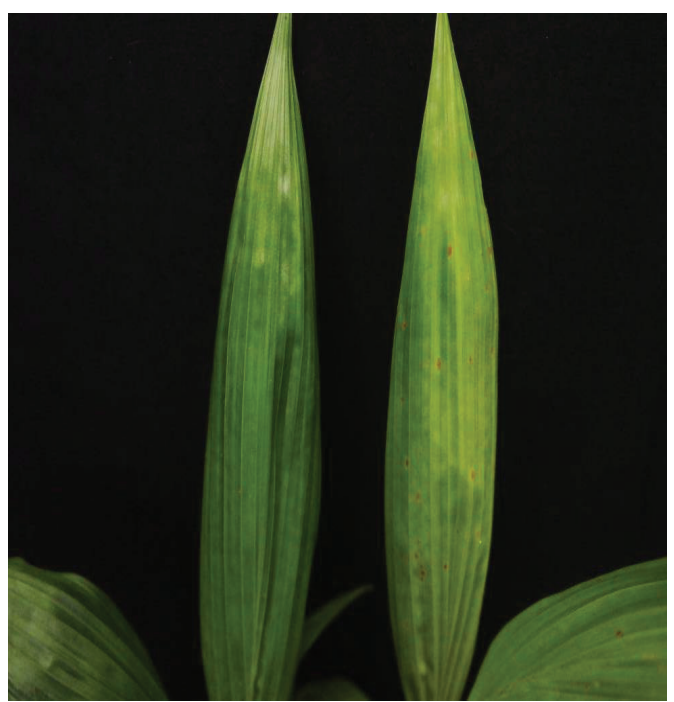

Figure 3. Curvularia leaf spot disease symptoms at $72 \mathrm{hr}$ after fungal inoculation; line number 187 (left) and line number 129 (right).

\section{CONCLUSION}

PR-proteins, chitinase and $\beta$-1,3-glucanase, in oil palm seedlings were induced by exposure to the fungal pathogen C. oryzae, and their activation levels could be used to indicate oil palm lines resistant to Curvularia leaf spot disease within $24 \mathrm{hr}$ after exposure, well before the appearance of any disease symptoms. Three lines (138, 187, and 203) showed high enzyme activities, while line 129 was the susceptible line that presented the lowest enzyme activities. When the proteins in oil palm leaves of lines 187 and 129 were separated by SDS-PAGE, line 187 expressed the protein bands with molecular weight ranges of chitinase and $\beta$-1,3-glucanase after fungal inoculation, but line 129 did not have visible protein bands. This study suggested that three oil palm tenera hybrid genotypes (138, 187 and 203) were the candidates to test field performance for disease resistance under farmers' commercial nursery conditions and also candidates for breeding and developing new oil palm varieties resistant to Curvularia leaf spot disease. 


\section{ACKNOWLEDGEMENT}

This work was supported by the government budget of Prince of Songkla University, PSU Ph.D graduate scholarship, Oil Palm Agronomical Research Centre: Phase 2 and Centre of Excellence in Agricultural and Natural Resources Biotechnology, Prince of Songkla University. Moreover, we are grateful to Associate Professor Dr Seppo Karrila, Faculty of Science and Industrial Technology, Prince of Songkla University, Surat Thani Campus, for helping to improve the manuscript.

\section{REFERENCES}

Agrios, G N (1997). Plant Pathology. Fourth edition. Academic Press, San Diego, USA. 635 pp.

Anfoka, G and Buchenauer, H (1997). Systemic acquired resistance in tomato against Phytophthora infestans by pre-inoculation with tobacco necrosis virus. Physiol. Mol. Plant Pathol. Vol. 50: 85-101.

Anguelova-Merha, V S; VanDer Westhuizen, A J and Pretorius, A (2001). $\beta$-1,3-glucanase and chitinase activities and the resistance response of wheat to leaf rust. J. Phytopathol. Vol. 149: 381-384.

Bowles, D J (1990). Defense-related proteins in higher plants. Ann. Rev. Biochem. Vol. 59: 873-907.

Bradford, M M (1976). A rapid and sensitive method for the quantitation of microgram quantities of protein utilizing the principle of protein-dye binding. Anal. Biochem. Vol. 72: 248-254.

Chairin, T and Petcharat, V (2017). Induction of defense responses in longkong fruit (Aglaia dookkoo Griff.) against fruit rot fungi by Metarhizium guizhouense. Biol. Control. Vol. 111: 40-44.

Durand-Gasselin, T; Asmady, H; Flori, A; Jacquemard, J C; Hayun, F; Breton, F and De Franqueville, H (2005). Possible sources of genetic resistance in oil palm (Elaeis guineensis Jacq.) to basal stem rot caused by Ganoderma boninense - Prospects for future breeding. Mycopathologia Vol. 159: 93-100.

Ebrahim, S; Usha, K and Sigh, B (2011). Pathogenesis related (PR) proteins in plant defense mechanism. Science against Microbial Pathogens: Communicating Current Research and Technological Advances (A Méndez-Vilas ed.). Vol. III. Badajoz: Formatex Research Center. p. 1043-1054.

Funnell, D L; Lawrence, C B; Pedersen, J F and Schardl, C L (2004). Expression of the tobacco $\beta-1,3-$ glucanase, PR-2d, following induction of SAR with
Peronospora tabacina. Physiol. Mol. Plant Pathol. Vol. 65: 285-296.

Gupta, P; Ravi, I and Sharma V (2013). Induction of $\beta$-1,3-glucanase and chitinase activity in the defense response of Eruca sativa plants against the fungal pathogen Alternaria brassicicola. J. Plant Interact. Vol. 8: 155-161.

Ham, K S; Kauffmann, S; Albersheim, P and Darvill, A G (1991). Host pathogen interaction. XXXIX. A soybean pathogenesis related protein with $\beta-1,3-$ glucanase activity releases phytoalexin elicitor-active heat-stable fragments from fungal walls. Mol. Plantmicrobe Interact. Vol. 4: 545-552.

Hegde, Y R and Keshgond, R S (2013). Role of pathogenesis-related proteins in plant disease management - A review. Indian J. Agric. Res. Vol. 34: $145-151$.

Idris, A S; Kushairi, A; Ismail, S and Ariffin, D (2004). Selection for partial resistance in oil palm progenies to Ganoderma basal stem rot. J. Oil Palm Res. Vol. 16: 12-18.

Ji, C and Kie, J (1996). Antifungal activity of cucumber $\beta-1,3$-glucanase and chitinase. Physiol. Mol. Plant Pathol. Vol. 49: 257-265.

Karthikeyan, M; Radhika, K; Mathiyazhagan, S; Bhaskaran, R; Samiyappan, R and Velazhahan, R (2006). Induction of phenolics and defense-related enzymes in coconut (Cocos nucifera L.) roots treated with biocontrol agents. Braz. J. Plant Physiol. Vol. 18: 367-377.

Karthikeyan, M; Jayakumar, V; Radhika, K; Bhaskaran, R; Velazhahan, R and Alice, D (2005). Induction of resistance in host against the infection of leaf blight pathogen (Alternaria palandui) in onion (Allium cepa var aggregatum). Indian. J. Biochem. Biophys. Vol. 42: 371-377.

Kittimorakul, J; Sunpapao, A; Duangpan, S; Anothai, $\mathrm{J}$ and Eksomtramage, T (2019). Screening of oil palm (Elaeis guineensis Jacq.) varieties for resistance to Curvularia leaf spot disease. Aust. J. Crop Sci. Vol. 13: 507-512.

Kittimorakul, J; Petcharat, V and Chuenchitt, S (2014). Chemical and biological control of Curvularia oryzae leaf spot of oil palm. Songklanakarin J. Pl. Sci. Vol. 1: 39-47.

Kittimorakul, J; Pornsuriya, C; Sunpapao, A and Petcharat, V (2013). Survey and incidence of leaf blight and leaf spot disease of oil palm seedling in Southern Thailand. Plant Pathol. J. Vol. 12: 149-153. 
Laemmli, UK (1970). Cleavage of structural proteins during the assembly of the head of bacteriophage T4. Nature Vol. 227: 680-685.

Mauch, F; Mauah-Mani, B and Boller, T (1988). Antifungal hydrolases in pea tissue: II. Inhibition of fungal growth by combinations of chitinase and $\beta$-1,3-glucanase. Plant Physiol. Vol. 88: 936-942.

Nyochenbeng, L M and Beyl, C A (2015). Induction and characterization of pathogenesisrelated proteins in roots of cocoyam [Xanthosoma sagittifolium (L) Schott] infected with Pythium myriotylum. Afr. J. Biotechnol. Vol. 14: 212-221.

Pareek, S S; Ravi, I and Sharma, V (2014). Induction of $\beta$-1,3-glucanase and chitinases in Vigna aconitifolia inoculated with Macrophomina phaseolina. J. Plant Interact. Vol. 9: 434-439.

Ren, Y Y and West, C A (1992). Elicitation of diterpene biosynthesis in rice (Oryza sativa L.) by chitin. Plant Physiol. Vol. 99: 1169-1178.
Sela-Buurlage, B M; Ponstein, S A; Bres-Vloemans, A S; Melchers, S L; Van Den Elzen, M J P and Cornelissen, C J B (1993). Only specific tobacco (Nicotiana tabacum) chitinases and $\beta$-1,3-glucanase exhibit antifungal activity. Plant Physiol. Vol. 101: 857-863.

Sunpapao, A; Kittimorakul, J and Pornsuriya, C (2014). Identification of leaf spot disease on oil palm seedling in nurseries of Thailand. Phytoparasitica Vol. 42: 529-533.

Syahanim, S; Abrizah, O; Mohamad Arif, A M; Idris, A S and Mohadin, A (2013). Identification of differentially expressed proteins in oil palm seedling artificially infected with Ganoderma: A proteomics approach. J. Oil Palm Res. Vol. 25: 298-304.

Theis, T and Stahl, U (2004). Antifungal protein: Target, mechanism and prospective applications. Cell Mol. Life Sci. Vol. 61: 437-455.

Verheye, W (2010). Growth and Production of Oil Palm. Land Use, Land Cover and Soil Sciences (Verheye, W H ed.). UNESCO-EOLSS Publishers, Oxford. p. 1-24. 